\title{
PROPERTIES OF CHARCOAL PRODUCED FROM REACTION WOOD IN TREES INCLINED DUE TO WIND ${ }^{1}$
}

Walter Torezani Neto Boschetti ${ }^{2 *}$, Matheus Perdigão de Castro Freitas Pereira ${ }^{3}$, Deborah Nava Soratto ${ }^{4}$, Ana Carolina $\mathrm{Boa}^{5}$, Angélica de Cássia Oliveira Carneiro ${ }^{6}$, Graziela Baptista Vidaurre ${ }^{7}$ and Ana Márcia Macedo Ladeira Carvalho 8

\footnotetext{
${ }^{1}$ Received on 04.04.2015 accepted for publication on 29.03.2017.

${ }^{2}$ Universidade Federal de Viçosa, Doutorado em Ciência Florestal, Viçosa, MG, Brasil. E-mail: <walterboschetti@gmail.com>.

${ }^{3}$ Universidade Federal de Viçosa, Mestrado em Ciência Florestal, Viçosa, MG, Brasil. E-mail: <matheus.perdigao@live.com>.

${ }^{4}$ Universidade Federal de Mato Grosso do Sul, Campus de Chapadão do Sul, Chapadão do sul, Brasil.E-mail:<deborahsoratto@gmail.com>.

${ }^{5}$ Universidade Federal do Espírito Santo, Programa de Pós-Graduação em Ciências Florestais, Jerônimo Monteiro, ES, Brasil. E-mail: <b.anacarol@yahoo.com.br>.

${ }^{6}$ Universidade Federal de Viçosa, Deprtamento de Engenharia Florestal, Viçosa, MG, Brasil. E-mail: <cassiacarneiro@ufv.br>.

${ }^{7}$ Universidade Federal do Espírito Santo, centro de Ciências Agrárias, Jerônimo Monteiro, ES, Brasil. E-mail:<grazividaurre@gmail.com>.

${ }^{8}$ Universidade Federal de Viçosa, Departamento de Engenharia Florestal, Viçosa, MG, Brasil. E-mail: <ana.marcia@ufv.br>.

*Corresponding author.
}

\begin{abstract}
Inclined trees produce reaction wood, whose properties are distinct from normal wood. This situation can affect the production of charcoal. This study was conducted to evaluate the quality of charcoal derived from reaction wood in trees of a commercial plantation inclined due to the action of wind. We used six year old wood from a Eucalyptus grandis $\mathrm{x}$ Eucalyptus urophylla hybrid from plantations located in Minas Gerais. The physical and chemical properties of the wood were determined as well as the gravimetric yield and charcoal properties. According to the results, there were significant differences between the properties of the reaction and normal wood, with the reaction wood having lower levels of lignin and extractives, greater holocellulose content and low specific gravity. However, these characteristics of reaction wood did not significantly affect the properties of its charcoal.
\end{abstract}

Keywords: Carbonization; Reaction wood; Wood properties.

\section{PROPRIEDADES DO CARVÃO VEGETAL PRODUZIDO COM MADEIRA DE REAÇÃO PROVENIENTE DE ARVORES INCLINADAS POR VENTOS}

\begin{abstract}
RESUMO - Árvores inclinadas produzem madeira de reação, cujas propriedades são distintas da madeira normal e, podem afetar na produção de carvão vegetal. Este trabalho foi realizado com objetivo de avaliar a qualidade do carvão vegetal procedente da madeira de reação em árvores de plantio comercial inclinadas por ação de ventos. Utilizou-se madeira de um híbrido de Eucalyptus grandis $x$ Eucalyptus urophylla aos seis anos de idade proveniente de plantios localizados em Minas Gerais. Determinaram-se as propriedades físicas e químicas da madeira, e também o rendimento gravimétrico e as propriedades do carvão vegetal. De acordo com os resultados, houve diferenças significativas entre as propriedades da madeira de reação e normal, tendo a madeira de reação menores teores de lignina e extrativos, maior teor de holocelulose e menor densidade básica. No entanto, essas diferenças na madeira de reação não afetaram significativamente as propriedades do carvão vegetal.
\end{abstract}

Palavras-Chave: Carbonização; Madeira de reação; Propriedades da madeira. 


\section{INTRODUCTION}

Wind action is a natural phenomenon that is impossible to control. Its occurrence in commercial plantations can create stress on the trees, affect the quality of the wood, and when it occurs with force, bursts can cause damage such as trunk inclination at different angles in the same planting.

The inclined stem produces reaction wood by biomechanical symmetry, in the attempt of the tree to return to the vertical axis. In hardwoods, this reaction wood is called tension wood and occurs in the upper part of the inclined stem. The reaction wood formed on the side opposite the slope is little studied due to the formation of suppressed wood on this side of the stem.

Tension wood has chemical and physical characteristics different to normal wood, due to differences in anatomical structure, mainly due to the presence of a gelatinous layer (Clair and Thibault, 2001; Washusen and Evans, 2001; Washusen and Ilic, 2001; Sousa, 2004).

Most of the eucalyptus forest plantations in Brazil are used to supply the pulp industry. However, the quality parameters of wood for cellulose production are affected, and may influence the process of cellulosic pulp and paper, when the chips of normal and reaction wood are not separated, as studied by Boschetti (2014). Another alternative for using this type of wood is its conversion into other products, such as charcoal. However, there are few studies that attest to the influence of this type of wood on the yield and quality of charcoal.

Charcoal quality is determined by the characteristics of the raw material used and the conversion technology. Some characteristics of reaction, tension and opposite wood, when compared to normal wood, are unfavorable for charcoal production, such as a lower lignin content. Therefore, verifying the characteristics of reaction wood from wind-inclined forest plantations is important to determine the yield and quality of the charcoal produced from this type of wood.

In this context, the objective of this work was to evaluate the quality of charcoal from the reaction wood in commercial tilted trees from wind action.

\section{MATERIALAND METHODS}

\subsection{Material}

Wood trees from Eucalyptus grandis $\mathrm{x}$ Eucalyptus urophylla hybrids, planted in flat ground, with a spacing of $3.00 \times 3.33 \mathrm{~m}^{2}$ were used in this study. These trees were struck by wind action 33 months after planting, causing some of the trees to tilt irreversibly. Harvesting occurred 38 months after the occurrence of the winds, and 71 months after planting. Ten trees were selected, with five of them presenting a straight stem (normal wood), and the other five a tilted stem (reaction wood).

The experiment was conducted on 10 trees, separated by two bands according to the tilt angle, with each band having five trees. In the control range, the trees had zero inclination, ie normal wood with a straight stem. The reaction wood came from the two range, where the trees were sloping between 20 and $35^{\circ}$ (Figure 1). The presence or absence of reaction wood in straight and tilted-stem trees on the longitudinal direction of the stem was confirmed through the pith eccentricity and through a double-coloring technique applied to histology glass slides, according to Boschetti et al., (2015a).

The angle of the trees was measured up to the commercial height of the trees, considering a minimum diameter of $6.0 \mathrm{~cm}$. At this point, the height coordinate (Y) was measured by means of the electronic relascope apparatus, and the variation of the stem in relation to the ground $(\mathrm{X})$ by measurement with a track. The angle of inclination of the trees $\left(\Theta^{\circ}\right)$ in relation to the vertical axis was adjusted by Equation 1, according to Boschetti et al., (2015b).

$$
\operatorname{Arctg} \theta^{\circ}=(\mathrm{X} / \mathrm{Y})
$$

where:

$\mathrm{X}$ is the inclination of the trunk in relation to the ground ( $\mathrm{m})$; $\mathrm{Y}$ is the vertical commercial height of the inclined tree $(\mathrm{m})$.

From each tree a $\log 75 \mathrm{~cm}$ long was extracted at the height of the DBH (diameter at breast height), the position where there was high incidence of reaction wood in the inclined trees. Peeled, the logs from the trees with a straight stem were divided in half from the pith, and denominated as 'side a' and 'side b' of the normal wood. Already the logs from the inclined trees, were divided by the eccentric of the pith, and

Revista Árvore. 2017;41(6):e410601 


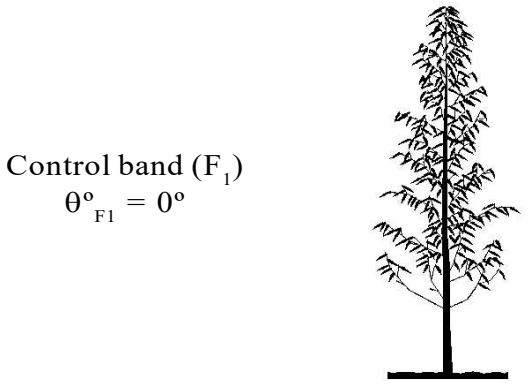

Figure 1 - Inclination bands of trees.

Figura 1-Faixas de inclinação das árvores.

demarcated on the upper and lower sides of the slope, distinguished as tension and opposite wood, respectively. Subsequently, all the divided logs were transformed into chips to determine the basic density of the wood, and carry out an analysis of the chemical composition. For the production of charcoal, a composite sample formed on the side $a+$ side $b$ was used for normal wood, and by tension + opposite wood for reaction wood. Subsequently the superior calorific value and the immediate chemical composition of charcoal were determined.

\subsection{Carbonization, wood and charcoal properties}

The basic density of the wood was obtained by NBR 1194 (ABNT, 2003). The extractive contents in the wood were determined according to TAPPI 264 om-88 (1998). Insoluble lignin was determined using the Klason method, modified according to the proposal of Gomide and Demuner (1986), derived from the TAPPI T 222 om- 88 norm. The soluble lignin was determined through spectrometry, as described by Goldschimid (1971), by diluting the filtrate obtained in the procedure to determine the insoluble lignin. The total lignin level was obtained by adding the two values of the soluble and insoluble lignin. The holocellulose content was obtained by adding the extractive and total lignin and subtracting 100 .

The carbonizations were performed in a laboratory muffle with electric heating; using wood chips, dried in a greenhouse at $103 \pm 2^{\circ} \mathrm{C}$, until achieving constant mass, and those samples were put in a metallic container.

The total time for carbonization of wood was 4.5 hours, the initial temperature was $30^{\circ} \mathrm{C}$, with the average heating rate of $1.66^{\circ} \mathrm{C} /$ minute for 3.5 hours

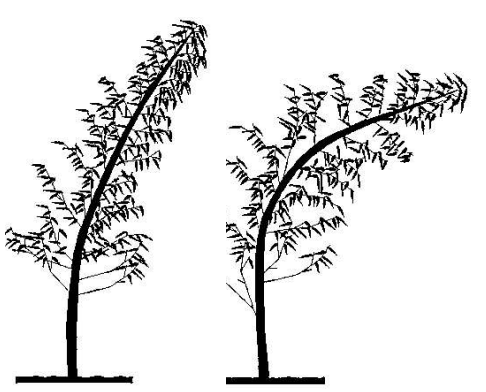

Band $2\left(\mathrm{~F}_{2}\right)$

$20^{\circ}<\theta^{\circ}{ }_{\text {F } 2} \leq 35^{\circ}$ up to $450{ }^{\circ} \mathrm{C}$, with the final temperature being $450^{\circ} \mathrm{C}$, stabilized for 60 minutes. After the carbonization, the gravimetric yields and condensable and noncondensable gases were determined using the dry mass of the wood, with the last characteristic being obtained by difference.

The superior calorific value of the wood and charcoal were determined in accordance with the method described by the NBR 8633 norm (ABNT, 1984), using an adiabatic calorimetric bomb. The wood samples were reduced using a laboratory mill of the Wiley kind, in accordance with the TAPPI 257 om-52 norm (TAPPI, 1998). The fraction collected was the material that passed through the international sieve n. 16, with 40 mesh, and were stuck in the international sieve n.24, with 60 mesh (ASTM, 1982). The samples were dried in a greenhouse at $103 \pm 2^{\circ} \mathrm{C}$, until reaching constant mass, in order to determine the superior calorific value.

To perform the immediate chemical analysis of the charcoal, the samples were ground and sieved to a particle size of approximately, $0.2 \mathrm{~mm}$ in accordance to the NBR 8112, with some adaptations, to determine the levels of volatile materials, ashes and fixed carbon, with dry base (ABNT, 1986).

\subsection{Statistical analysis}

The data obtained were submitted to the Lilliefors and Cochran tests, to verify the normality and homogeneity of the variances, respectively. For the data of the wood quality analyses a completely randomized design was adopted, with the treatments arranged in a scheme of sub-split plots with five replications, with the plots representing the tilt range, and the subplots the stem sides (side a, side b, tension, 
and opposite wood). The results of the charcoal properties were submitted to analysis of variance. When significant differences were observed, a comparison between the different treatments was undertaken using the Tukey test at $5 \%$ of significance.

\section{RESULTS}

The properties of eucalyptus wood were affected by the inclination of the trees (Table 1). It was observed that reaction, tension and opposite wood, had properties significantly different from normal wood. The wood from the inclined trunk showed significantly lower values for basic density and total lignin, characteristics not desirable for the production of charcoal.

The gravimetric yield and the charcoal properties were not influenced by the quality of the wood from inclined trees (Table 2).

\section{DISCUSSION}

In general, the normal and reaction wood, used for the production of charcoal, have a basic density classified as low, around $0.47 \mathrm{~g} . \mathrm{cm}^{-3}$. It can be observed in Table 1 that reaction wood had the lowest average values for basic density compared to normal wood, with a reduction of approximately $6 \%$. In addition, it is noticed that the reduction of basic density in the reaction wood is a consequence of the lower values obtained by the opposite wood.

The basic density of wood is directly related to the production of energy, ie, the higher the density, the greater the amount per cubic meter of energy stored (Carneiro et al., 2014). Additionally, the density of charcoal tends to reflect the density of the wood. Santos et al. (2011) pointed out that higher wood density values tend to generate charcoal with higher density and higher gravimetric yield.

There was a reduction of $35.7 \%$ and $13.6 \%$ in extractive and total lignin contents, respectively, in the reaction wood compared with normal wood. On the other hand, the reaction wood had an increase of $8.5 \%$ in holocellulose content. It was also found that opposite wood has a higher percentage of holocellulose compared to normal wood.

Sousa (2004) explains that the gelatinous layer inside the fibers of the tension wood is composed basically of cellulose, which explains the increased content of holocellulose in the tension wood and, consequently, the decrease in lignin content. It is observed that the tension wood had a $10.4 \%$ increase in holocellulose content when compared to normal wood and a $16.5 \%$ reduction in lignin content. Baba et al. (1996) observed a 70\% reduction in lignin content

Table 1 - Physical and chemical properties of wood

Tabela 1 - Propriedades físicas e químicas da madeira.

\begin{tabular}{|c|c|c|c|c|c|c|c|c|c|c|c|}
\hline Walter & & & & & & d prope & & & & & \\
\hline Materia & & $\begin{array}{c}\text { DB } \\
\left(\mathrm{g} . \mathrm{cm}^{-3}\right) \\
\end{array}$ & $\begin{array}{c}\text { DB } \\
\left(\mathrm{g} . \mathrm{cm}^{-3}\right) \\
\end{array}$ & $\begin{array}{l}\text { LIG } \\
(\%) \\
\end{array}$ & $\begin{array}{l}\text { LIG } \\
(\%)\end{array}$ & $\begin{array}{c}\text { HOLO } \\
(\%)\end{array}$ & $\begin{array}{c}\text { HOLO } \\
(\%)\end{array}$ & $\begin{array}{c}\text { EXT } \\
(\%)\end{array}$ & $\begin{array}{c}\text { EXT } \\
(\%) \\
\end{array}$ & $\begin{array}{c}\text { ASHES } \\
(\%)\end{array}$ & $\begin{array}{c}\text { ASHES } \\
(\%)\end{array}$ \\
\hline $\begin{array}{c}\text { Normal } \\
\text { Wood }\end{array}$ & $\begin{array}{l}\text { Side A } \\
\text { Side B }\end{array}$ & $\begin{array}{l}0,49 \text { a } \\
0,49 \text { a }\end{array}$ & 0,49 a & $\begin{array}{l}32,4 \text { a } \\
32,1 \text { a }\end{array}$ & 32,2 a & $\begin{array}{l}63,3 \mathrm{~b} \\
63,8 \mathrm{~b}\end{array}$ & $63,6 \mathrm{~b}$ & $\begin{array}{l}4,3 \mathrm{a} \\
4,0 \mathrm{a}\end{array}$ & $4,2 \mathrm{a}$ & $\begin{array}{l}0,32 \text { a } \\
0,33 \text { a }\end{array}$ & $0,33 \mathrm{~b}$ \\
\hline $\begin{array}{c}\text { Rection } \\
\text { Wood }\end{array}$ & $\begin{array}{l}\text { TW } \\
\text { OW }\end{array}$ & $\begin{array}{l}0,49 \mathrm{a} \\
0,44 \mathrm{~b}\end{array}$ & $0,46 \mathrm{~b}$ & $\begin{array}{l}26,9 \mathrm{~b} \\
28,7 \mathrm{~b}\end{array}$ & $27,8 \mathrm{~b}$ & $\begin{array}{l}70,2 \mathrm{a} \\
68,8 \mathrm{a}\end{array}$ & $69,5 \mathrm{a}$ & $\begin{array}{l}2,9 \mathrm{a} \\
2,5 \mathrm{~b}\end{array}$ & $2,7 \mathrm{~b}$ & $\begin{array}{l}0,36 \text { a } \\
0,38 \text { a }\end{array}$ & $0,37 \mathrm{a}$ \\
\hline
\end{tabular}

$\mathrm{TW}=$ tension wood; $\mathrm{OP}=$ opposite wood; $\mathrm{BD}=$ basic density; LIG, HOLO, EXT, ASHES = represent the total lignin, holocellulose, total extractives, and ashes, respectively. Averages followed by the same lowercase letter in the column do not differ from each other at $5 \%$ significance by the Tukey test, in the scheme of subdivided parcels.

Table 2 - Gravimetric yield and charcoal properties.

Tabela 2 - Rendimento gravimétrico e propriedades do carvão vegetal.

\begin{tabular}{|c|c|c|c|c|c|c|c|}
\hline \multirow[t]{2}{*}{ Material } & \multicolumn{7}{|c|}{ Charcoal properties } \\
\hline & $\begin{array}{l}\text { GYC } \\
(\%)\end{array}$ & $\begin{array}{l}\text { CG } \\
(\%)\end{array}$ & $\begin{array}{c}\text { NCG } \\
(\%)\end{array}$ & $\begin{array}{c}\text { Volatile } \\
(\%)\end{array}$ & $\begin{array}{c}\text { Ashes } \\
(\%)\end{array}$ & $\begin{array}{c}\text { CFCC } \\
(\%)\end{array}$ & $\begin{array}{c}\mathrm{SCVW} \\
(\mathrm{kcal} / \mathrm{kg})\end{array}$ \\
\hline Normal Wood & 26,8 & 50,7 & 22,5 & 11,4 & 0,81 & 87,8 & 8342 \\
\hline Reaction Wood & 25,3 & 53,8 & 20,7 & 11,8 & 0,99 & 87,2 & 8207 \\
\hline
\end{tabular}

$\mathrm{GYC}=$ gravimetric yields of charcoal; $\mathrm{GC}$ and $\mathrm{GNC}=$ condensable and non-condensable gases, respectively. Volatile, $\mathrm{Ashes} \mathrm{CFCC}=$ represent the contents of volatile materials, ashes, fixed carbon, respectively; SCVW = superior calorific value of charcoal. The values were not significant by the Tukey test with $5 \%$ of significance.

Revista Árvore. 2017;41(6):e410601 
in the Eucalyptus camaldulensis wood, compared to normal wood.

Regarding the properties of wood for charcoal production, Santos et al. (2011) have pointed out that during the carbonization process, lignin contributes to the gravimetric yield and, on the other hand, the extractives and holocellulose contribute little to the charcoal yield. Zanuncio et al. (2014) state that the total extractive content in the wood is directly related to the gravimetric yield and the calorific value of charcoal. In this context, the quality of the reaction wood would be lower to obtain charcoal. However, when analyzing Table 2, it is noticeable that most of the charcoal properties and the gravimetric yield of the reaction wood were not significantly affected by the inferiority of the quality of the reaction wood of the inclined trees.

Carneiro et al. (2014) pointed out that fixed carbon content associated with other properties is one of the most important parameters for the production of charcoal, since it is mainly responsible for the energy stored in charcoal. In the carbonization process, the relationship between the fixed carbon content and the gravimetric yield is inversely proportional. In this way, the low gravimetric yield of the charcoal observed can be explained by the high fixed carbon content present in the charcoal coming from the studied wood. Thus, the high fixed carbon content found in the eucalyptus charcoal under study contributed to increasing the calorific power, as shown in Table 2.

On the other hand, the low gravimetric yield and the higher fixed carbon content in the normal and reaction wood can be explained by the chemical composition of the wood, due to the higher content of holocellulose, as a result of the genetic material being destined for cellulose production. Frederico (2009) explains that cellulose and hemicelluloses contribute little to the gravimetric yield, because it is less resistant to thermal degradation, leading to intense degradation during carbonization, generating a larger portion of condensable and non-condensable gases, as evidenced by the values in Table 2, and consequently, entails a higher fixed carbon concentration in the charcoal formed.

The mean values observed for the superior calorific value (SCV) of charcoal varied between 8.207 and 8.342 $\mathrm{kcal} / \mathrm{kg}$, and were similar to those studied by Santos et al. (2011) using the same hybrid at seven years, who found SCV varying between 8.210 and $8.515 \mathrm{kcal} / \mathrm{kg}$.
The same authors point out that charcoal with higher calorific value, mainly for steel employment, lower consumption of reducing input, given the same productivity.

Oliveira et al. (2012) emphasize that good quality charcoal for the steel industry should have: a high apparent relative density, high calorific value, low humidity, low volatile and ash content, and high fixed carbon content. By analyzing the data in Table 2 and comparing them to the same hybrid studied by other authors, it can be seen that charcoal from both normal and reaction wood presents good characteristics for energy use, in terms of its low content of volatile materials, ash content, and high fixed carbon content, despite the low gravimetric yield found.

For Arantes et al. (2013) the charcoal from normal and reaction wood of the hybrid studied at the same age, presented lower volatile materials content and higher fixed carbon content, in terms of carbonized genetic material, while for Oliveira et al. (2012) the wood was seven years old, both using the same carbonization methodology, with the wood of the cited authors being obtained from energetic forests. The higher the fixed carbon content and the lower the volatile materials content in charcoal, the more suitable for the steel industry, due to the lower speed of energy release of charcoal (Brand, 2010).

When the purpose of the eucalyptus wood is the production of cellulose, it is desirable that it presents low cellulose and hemicellulose levels. This is because such components are less resistant to thermal degradation of wood, undergoing intense degradation during carbonization and giving rise to a larger proportion of condensable and non-condensable gases formed, contributing little to the gravimetric yield of charcoal (Frederico, 2009).

The ashes are derived from the mineral content of the wood and their quantification is important, because high levels require more cleaning in furnaces and other systems. Additionally, in blast furnaces, the ash increases the consumption of charcoal and causes premature wear of the refractory. The ash content of charcoal from normal and reaction wood is within the range recommended by Santos (2008) for the steel industry, which determines ideal levels of ash present in charcoal of less than $1 \%$.

Revista Árvore. 2017;41(6):e410601 


\section{CONCLUSIONS}

The presence of reaction wood influenced the properties of the wood in a significant way in inclined trees, both in density and chemical composition. However, this variation did not significantly influence the gravimetric yield and coal properties, including for the steel industry. It was concluded that an alternative for the use of inclined trees affected by the action of the winds in forest plantations is carbonization for the production of charcoal.

\section{REFERENCES}

Arantes MDC, Trugilho PF, Silva JRMD, Andrade CR. Características do carvão de um clone de Eucalyptus grandis W. Hill ex Maiden x Eucalyptus urophylla $\mathrm{S}$. T.

Blake. Cerne.2013;19(3):423-31.

Associação Brasileira de Normas Técnicas ABNT. NBR 1194: madeira: determinação da densidade básica. Rio de Janeiro: 2003.

Associação Brasileira de Normas Técnicas ABNT. NBR 8112: carvão vegetal: análise imediata. Rio de Janeiro: 1986.

Associação Brasileira de Normas Técnicas ABNT. NBR 8633: carvão vegetal: determinação do poder calorifico. Rio de Janeiro: 1984.

American Society for Testing and Materials ASTM. Standard methods of evaluating properties of wood-base fiber and particles materials. Philladelphia: 1982.

Baba K, Ona T, Takabe K, Itoh T, Ito K. Chemical and anatomical characterization of the tension wood of Eucalyptus camaldulensis L. Mokuzai Gakkaishi. 1996;42:795-8.

Brand MA. Energia de biomassa florestal. Rio de Janeiro: Interciência; 2010.

Boschetti WTN. Qualidade da madeira de árvores de clone de Eucalyptus grandis $x$ Eucalyptus urophylla inclinadas por ação de ventos para produção de celulose [dissertação] Jerônimo Monteiro: Universidade Federal do Espírito Santo; 2014.

Boschetti WTN, Paes JB, Oliveira JTS, Dudecki L. Características anatômicas do lenho de reação de árvores inclinadas de eucalipto para produção de celulose. Pesquisa Agropecuária Brasileira. 2015a;50(6):459-69.

Boschetti WTN, Paes JB, Vidaurre GB, Arantes MDC, Leite FP. Parâmetros dendrométricos e excentricidade da medula em árvores inclinadas de eucalipto. Scientia Forestalis. 2015b;43(108):781-9.

Carneiro ACO, Castro AFNM, Castro RVO, Santos RC, Ferreira LP, Damásio RAP et al. Potencial energético da madeira de Eucalyptus sp. em função da idade e de diferentes materiais genéticos. Revista Árvore. 2014;38:375-81.

Clair B, Thibault B. Shrinkage of the gelatinous layer of poplar and beech tension wood. IAWA Journal. 2001;22(2):121-31.

Frederico PGU. Influência da densidade e composição química da madeira sobre a qualidade do carvão de Eucalyptus grandis W. Hill ex Maiden e de híbridos de Eucalyptus grandis $\mathrm{x}$ Eucalyptus urophylla S.T. Blake [dissertação]. Viçosa, MG: Universidade Federal de Viçosa; 2009.

Goldschimid O. Ultraviolet spectra. In: Sarkanen $\mathrm{KV}$, Ludwig CH editors. Lignins. New York: Wiley Interscience; 1971. p.241-66.

Gomide JL, Demuner BJ. Determinação do teor de lignina em material lenhoso: método Klason modificado. O Papel. 1986;47(8):36-8.

Oliveira AC, Rocha MFV, Pereira BLC, Carneiro ADCO, Carvalho AMML, Vital BR. Avaliação de diferentes níveis de desbaste nas propriedades da madeira e do carvão vegetal de Eucalyptus grandis $x$ Eucalyptus urophylla.

Floresta.2012;42:59-68.

Santos ID. Influência dos teores de lignina, holocelulose e extrativos na densidade básica, contração da madeira e nos rendimentos e densidade do carvão vegetal de cinco espécies lenhosas do cerrado [dissertação] Brasília, DF: Universidade de Brasília; 2008.

Santos RC, Carneiro ACO, Castro AFM, Castro RVO, Bianche JJ, Souza MM et al. Correlações entre os parâmetros de qualidade da madeira e do carvão vegetal de clones de eucalipto. Scientia Forestalis. 2011;39(90):221-30.

Revista Árvore. 2017;41(6):e410601 
Sousa LC. Caracterização da madeira de tração em Eucalyptus grandis e sua influência na produção de polpa celulósica [dissertação] Viçosa, MG:

Universidade Federal de Viçosa; 2004.

Tappi Technical Divisions and Committees. TAPPI test methods. Atlanta: 1998. 46p.

Washusen R, Evans R. The association between cellulose crystallite width and tension wood occurrence in Eucalyptus globulus. IAWA Jounal.
2001;22:235-43.

Washusen R, Ilic J. Relationship between transverse shrinkage and tension wood from three provenances of Eucalyptus globulus Labill. Holz als Roh-und Werkstoff. 2001;59:85-93.

Zanuncio AJV, Carvalho AG, Trugilho PF, Monteiro TC. Extractives and energetic properties of wood and charcoal. Revista Árvore. 2014;38:369-74. 
BOSCHETTI WTN et al.

Revista Árvore. 2017;41(6):e410601 